\title{
IDENTIFIKASI MODALITAS BELAJAR VAK KOMBINASI SISWA DALAM PELAJARAN MATEMATIKA SMP NEGERI 1 ARJASA JEMBER
}

\author{
Dwi Noviani Sulisawati', Lutfiyah'2, Luzainiatus Sukma ${ }^{3}$ \\ 1,2Pendidikan Matematika IKIP PGRI Jember, SMAI Miftahul Afkar Kraksan ${ }^{3}$
}

dwi.moshimoshi@gmail.com ${ }^{1}$, azkalutfimh@gmail.com²,luzai.n.sukma@gmail.com³

\begin{abstract}
Abstrak
Modalitas belajar atau yang sering kita sebut dengan gaya belajar adalah salah satu faktor utama penentu kecepatan siswa dalam memahami dan menerima informasi yang diberikan kepadanya. Artikel ini bertujuan untuk melakukan identifikasi berbagai macam kombinasi gaya belajar visual, audio, dan kinestetik yang ada di kelas VIII SMPN 1 Arjasa Jember. Penelitian ini merupakan penelitian deskriptif yang digunakan sebagai data awal untuk proyek penelitiantentang analisis penyelesaian masalah siswa berdasarkan gaya belajar. Data pada penelitian ini diperoleh melalui pengumpulan angket yang dibagikan kepada 58 siswa kelas VIIIA dan VIIIByang ditentukan dengan menggunakan teknik sampling area. Sedangkan untuk angket yang digunakan peneliti dalam proses pengambilan data, sebelumnya telah dinyatakan valid secara kualitatif oleh 2 orang ahli psikologi. Hasil penelitian menunjukkan bahwa secara keseluruhan gaya belajar paling banyak yang dimiliki oleh siswa kelas VIII di SMP Negeri 1 Arjasa adalah gaya belajar visual dengan rincian sebaran persentase gaya belajar sebagai berikut: visual sebanyak $44,83 \%$, audio sebanyak 31,04\%, kinestetik sebanyak 5,17\%, visualaudio sebanyak 15,52\%, audio-kinestetik sebanyak 1,72\%, dan $1,72 \%$ untuk gaya belajar visual-audio-kinestetik.
\end{abstract}

Kata kunci: gaya belajar, VAK kombinasi, siswa SMP

\begin{abstract}
The modality of learning or what we often refer to as learning styles is one of the main factors determining the speed of students in understanding and receiving information given to them. This article aims to identify various combinations of visual, audio, and kinesthetic learning styles that exist in $8^{\text {th }}$ grade of SMPN 1 ArjasaJember. This research is a descriptive study that is used as preliminary data for a research project about analyzing students problem solving based on learning styles. The data in this study were obtained through questionnaire collection that was distributed to 58 students of class 8th A grade and 8th B grade which were determined using area sampling technique. As for the questionnaire used by researchers in the process of collecting data, previously it has been declared qualitatively valid by 2 psychologists. The results showed that overall the most learning styles possessed by eighth grade students at SMP Negeri 1 Arjasa were visual learning styles with details of the percentage distribution of learning styles as follows: visual as much as $44.83 \%$, audio as much as $31.04 \%$, kinesthetic as much as $5.17 \%$,
\end{abstract}


visual-audio as much as $15.52 \%$, audio-kinesthetic as much as $1.72 \%$, and $1.72 \%$ for visual-audio-kinesthetic learning styles.

Keywords: learning style, VAK combination, Middle School students

\section{PENDAHULUAN}

Artikel ini merupakan salah satu bentuk gambaran kecil hasil penelitian yang telah kami laksanakan. Penelitian ini merupakan sebagian kecil dari proyek penelitian kami tentang analisis penyelesaian masalah siswa berdasarkan gaya belajar. Data yang kami dapatkan nantinya adalah berkenaan dengan data hasil identifikasi modalitas (gaya belajar) siswa yang akan kami gunakan sebagai data penunjang dalam proyek penelitian tentang analisis penyelesaian masalah siswa berdasarkan gaya belajar. Sebenarnya isi penelitian ini ialah menjelaskan dan mengidentifikasi keberagaman modalitas (gaya belajar) yang mayoritas dimiliki siswa dan telah banyak dilakukan oleh peneliti lain dengan subjek yang berbeda, tetapi dalam penelitian kami ini, kami merancang angket sedemikian rupa sehingga kami mampu menjaring jenis gaya belajar kombinasi (tidak hanya audio, visual dan kinestetik). Sehingga data dari hasil penelitian ini menjadi sangat penting bagi kami karena selain menjadi data penunjang kami dalam mengetahui modalitas belajar yang dominan pada kelas yang ditentukan juga untuk mengetahui seberapa banyak jumlah siswa yang memiliki gaya belajar kombinasi, sehingga hal ini dapat mempermudah kami untuk melanjutkan penelitian kami berikutnya.

Permasalahan yang seringkali dihadapi oleh Guru-Guru yang mengajar pada setiap jenjang salah satunya ditemukan pada pembelajaran yang ditujukan untuk siswa SMP (Sekolah Menengah Pertama). Permasalahan tersebut dapat dipengaruhi oleh beberapa faktor yakni tentang perkembangan fisik, perkembangan emosi, perkembangan sosial serta perkembangan intelektual yang sedang terjadi pada anak usia Sekolah Menengah Pertama. Secara usia, anak usia SMP memiliki rentang usia antara 12 hingga tertinggi 18 tahun (Permen No 17, 2017). Pada usia ini, menurut Piaget (Kemendikbud, 2016) meyakini bahwa perkembangan intelektual anak SMP berada pada akhir tahap operasional konkrit (rentang usia antara 7sampai usia11 tahun) dan memasuki tahap operasional formal (rentang usia 11 sampai usia15 tahun). Perubahan tahap perkembangan ini yang memungkinkan siswa juga mengalami berbagai hal yang berbeda dalam kemampuan menerima dan mengolah informasi.

Selain akibat perbedaan tahap perkembangan intelektual, bakat matematika juga merupakan salah satu faktor lain yang patut diperhatikan oleh Guru untuk mengamati kemampuan siswa SMP dalam menerima dan mengolah informasi. Siswa dengan bakat matematika luar biasa hanya 
terdapat sekitar 2-3\% dari populasi siswa di dunia (Miller, 1990). Ciri-ciri siswa yang memiliki bakat matematika menurut Elliot (2013) adalah sebagai berikut: (1) Siswa mampu menyatakan masalah secara spontan, (2) Dapat bekerja dengan data dengan fleksibel, (3) lancar dalam mengungkapkan ideide matematikanya, (4) mampu mengorganisasi data, (5) penafsiran yang orisinal, (6) cepat dalam mempelajari konsep matematika yang baru, (7) terampil dan mendalam dalam kemampuan mengobservasi, (8) terampil mengajukan pertanyaan yang bermutu, (9) pemahaman yang dimiliki sangat mendalam, (10) memiliki cara penyelesaian masalah yang unik, dan (11) mampu memberikan kesimpulan berdasarkan pola tertentu yang dimiliki. Tetapi Miller (Kemendikbud, 2016) menyatakan jika terdapat beberapa siswa dengan bakat matematika mereka yang tidak menunjukkan prestasi akademik yang menonjol, mereka juga tidak menunjukkan antusiasme-nya dalam mengikuti kegiatan pembelajaran ataupun tidak menempati peringkat yang tinggi di kelasnya. Salah satu faktonya adalah pola pembelajaran yang dirasa kurang mengakomodasi perbedaan setiap individu dan gaya mengajar Guru yang kurang fleksibel.

Modalitas belajar atau yang lebih sering kita kenal luas sebagai gaya belajar adalah salah satu dari sekian banyak faktor yang dapat menentukan keberhasilan siswa dalam memahami setiap proses belajar mengajar yang diberikan oleh guru kepada mereka. Sebagaimana hasil penelitian Saputra (2018) yang mencatat bahwa "adanya hubungan signifikan antara gaya belajar yang dimiliki siswa dengan hasil belajar matematika siswa kelas IV SDN 1 Way Laga Bandar Lampung TA 2017/2018". Lebih lanjut Rezaeinejad, etc (2015) menyatakan bahwa menurut koefisien korelasi, ada hubungan yang positif signifikan antara siswa yang memiliki gaya belajar aktif-reflektif dan visualverbal dengan hasil belajarnya di bidang matematika. Modalitas belajar merupakan salah satu karakteristik yang sebelumnya harus telah diketahui oleh guru sebagai persiapan bagi mereka sebelum mereka melaksanakan proses pembelajaran untuk melakukan transfer ilmu kepada siswa mereka di dalam kelas. Gaya belajar didefinisikan sebagaisuatu kombinasi yang dapat menjelaskan tentang proses siswa dapat menyerap, mengatur dan mengolah berbagai informasi yang mereka dapatkan dari sumber lain (DePorter dan Hernacki, 2016). Sedangkan Nasution (Sundayana, 2016) menyampaikan bahwa "gaya belajar adalah kebiasaan yang sering dilakukan untuk menangkap informasi atau stimulus dan cara mengingat/berpikir untuk menyelesaikan suatu masalah". Dalam satu kelas sangat memungkinkan jika siswa-siswa memiliki perbedaan gaya belajar antara satu dengan yang lain. Hal inilah yang memungkinkan terjadinya keberagaman kesulitan siswa dalam memahami, menerima, mengolah dan melakukan transfer informasi kepada orang lain. Sehingga sangat disarankan jika seorang Guru sebaiknya 
mamu menyajikan bahan pelajaran yang telah disesuaikan dengan modalitas belajar yang dimiliki oleh para siswanya (Syahruddin, 2016).

Claxton dan Murrel (Gunawan, 2003: 140) membagi gaya belajar siswa menjadi 4 kelompok yang terdiri dari "(1) Model kepribadian, meliputi field independence, independence, personality types, reflection versus impulsivity, the omnibus personaliyu inventory dan holland typologi of personality; (2) Model Pemrosesan informasi, meliputi holists versus serialists, sequencing, deep elaborative versus shallow-reiterative, experiental learning dan innate predisposition; (3)Model interaksi sosial, meliputiclusters based on behavior, students' response styles dan dependent atau collaborative atau independent behavior; (4) Model pilihan pengajaran, meliputicognitive style mappingdan hirarki kebutuhan dari Maslow dan motivasi berprestasi milik McClelland". Sedangkan, nasution (Widiyanti, 2011) menyatakan bahwa gaya belajar sebenarnya terbagi menjadi 5 bagian, yang meliputi (1) visual/ pengelihatan, (2) auditori/ pendengaran, (3) tectile/ kinestetik/ peraba/ gerakan, (4) olfactory/ penciuman, dan (5) gustatory/ pengecapan. Selain itu, pihak De Porter dan Hernacki (2016) membagi klasifikasi gaya belajar menjadi 3 bagian besar yang berbeda, diantaranya (1) Gaya belajar visual, (2) Gaya belajar audio, dan (3) Gaya belajar kinestetik.

Pada hakikatnya, semua siswa memiliki gaya belajar yang telah disebutkan di atas, tetapi tidak semuanya berkembang dan memiliki kecenderungan yang berbeda yang memungkinkan terjadi adanya salah satu atau kombinasi modalitas belajar tersebut yang mendominasi pada siswa. Gaya belajar visual ialah suatu gaya belajar dimana siswa akan lebih memanfaatkan indera pengelihatan.

"Orang dengan gaya belajar visual lenbih memilih untuk melihat atau membayangkan apa yang sedang dia bicarakan. Selain itu, orang tersebutpeka terhadap warna dancukup paham terhadappadapermasalahan artistic. Hanya dirinya akan menemui kendala jika melakukan dialog secara langsung sebab dirinya memiliki reaksi yang kurang baik terhadap suara, hingga sulit jika diminta untuk mengikuti anjuran secara lisan dan sering salah mendefinisikan kata atau ucapan" (Hamzah,2008).

Sehingga siswa visual akan lebih mudah menerima, mengingat dan mengolah informasi yang didapat dengan menyaksikan langsung dari sumber informasi tersebut (Wahyuni, 2017). Sedangkan menurut Bobby De Porter dan Mike Hernacki (Depoter,2016) sebagai berikut.

"Ciri- ciri siswa dengan auditorial adalah (a) sering berbicara sendiri ketika sedang bekerja, (b) sulit berkonsentrasi di tempat yang bising, (c) lebih suka membaca keras dan mendengarkan, (d) kemampuannya dalam menulis tidak terlalu menonjol, tetapipandai bercerita, (e) baginya, belajar lebih mudah melalui cara mendengarkan serta akan mampu mengingat dengan baik 
apa yang didiskusikan daripada apa yang dilihatnya, (f)suka melakukan diskusi dan menjelaskan sesuatu panjang lebar".

Sedangkan lebih lanjut menurut Bobby De Porter dan Mike Hernacki (Deporter,2000) sebagai berikut.

"Ciri-ciri siswa dengan gaya belajar kinestetik yaitu a) berbicara pelan dan lambat, b) sulit mengingat peta kecuali jika dirinya pernah berada ditempat itu, c) ketika menghafal dilakukan sambil berjalan dan melihat, d) menggunakan jari sebagai petunjuk saat membaca, e) tidak dapat duduk diam untuk waktu yang lama, f) kemungkinannya tulisannya jelek, g) selalu berorientasi pada fisik dan banyak bergerak, h) ingin melakukan segala sesuatu".

Sehingga berdasarkan pemaparan yang telah diberikan sebelumnya, maka peneliti ingin mengetahui tentang identifikasi persebaran modalitas (gaya) belajar siswa kelas VIIIA dan VIIIB SMPN 1 Arjasa Jember.

\section{METODE PENELITIAN}

Penelitian ini adalah penelitian deskriptif yang bertujuan untuk mengidentifikasi berbagai gaya belajar VAK yang mungkin terdapat dalam lingkup pembelajaran. Pengabilan subjek pada penelitian ini menggunakan teknik purposive sampling yang melibatkan 58 siswa kelas VIIIA dan VIIIB dengan populasi seluruh siswa kelas VIII SMP Negeri 1 Arjasa Jember. Purposive sampling digunakan sebagai teknik pengambilan data sebab hal ini berkaitan dengan proyek penelitian besar yang menaungi penelitian ini yaitu kelas yang memiliki kemampuan matematika tinggi yang diasumsikan akan dapat menyelesaikan permasalahan lebih lanjut yang akan diajukan peneliti. Data yang akan diolah diperoleh melalui teknik angket yang disebarkan dan diisi oleh seluruh siswa kelas VIIIA dan VIIIB untuk kebutuhan pemetaan gaya belajar yang mereka milki. Angket tersebut berisi 63 item pertanyaan yang telah divalidasi secara kualitatif oleh 2 orang psikolog dan satu orang dosen pendidikan matematika. Item-item pertanyaan yang ada pada angket menunjukkan ciri-ciri masing-masing gaya belajar yang dimaksud dengan kisikisi sebagai berikut.

Tabel 1 Kisi-Kisi Angket Gaya Belajar

\begin{tabular}{llcc}
\hline \multirow{2}{*}{ Gaya Belajar } & \multicolumn{1}{c}{ Indikator } & \multicolumn{2}{c}{ Nomor Pernyataan } \\
\cline { 2 - 4 } 1. Visual & $\begin{array}{l}\text { Memperhatikan kerapian } \\
\text { dan keteraturan }\end{array}$ & 1 dan 2 & 8 \\
\cline { 2 - 4 } & $\begin{array}{l}\text { Mengingat apa yang dilihat lebih } \\
\text { baik daripada apa yang didengar }\end{array}$ & 12 dan 17 & 3 \\
\cline { 2 - 4 } & Mengingat dengan asosiasi visual & 10 dan 18 & 13 \\
\hline
\end{tabular}


Lanjutan Tabel 1 Kisi-Kisi Angket Gaya Belajar

\begin{tabular}{|c|c|c|c|}
\hline \multirow{2}{*}{ Gaya Belajar } & \multirow{2}{*}{ Indikator } & \multicolumn{2}{|c|}{ Nomor Pernyataan } \\
\hline & & Positif & Negatif \\
\hline & $\begin{array}{l}\text { Tidak terganggu dengan kondisi } \\
\text { sekitarnya yang ribut }\end{array}$ & 5 dan 6 & 4 \\
\hline & $\begin{array}{l}\text { Bermasalah dalam mengingat } \\
\text { instruksi verbal kecuali jika } \\
\text { ditulis, dan sering meminta } \\
\text { bantuan yang lain untuk } \\
\text { mengulangnya }\end{array}$ & 7 dan 9 & 11 \\
\hline & $\begin{array}{l}\text { Lebih memilih membaca } \\
\text { dibandingkan dibacakan }\end{array}$ & 14 dan 21 & 19 \\
\hline & $\begin{array}{l}\text { Tidak pandai memilih kata dalam } \\
\text { bebicara. }\end{array}$ & 16 dan 20 & 15 \\
\hline \multirow[t]{7}{*}{ 2. Audio } & $\begin{array}{l}\text { Mudah terganggu oleh } \\
\text { keributan }\end{array}$ & 23 dan 26 & 29 \\
\hline & $\begin{array}{l}\text { Melakukan gerakan-gerakan bibir } \\
\text { dan mengucapkan tulisan di buku } \\
\text { ketika membaca }\end{array}$ & 32 dan 36 & 30 \\
\hline & $\begin{array}{l}\text { Lebih suka membaca dengan } \\
\text { keras serta mendengar }\end{array}$ & 33 dan 34 & 36 \\
\hline & $\begin{array}{l}\text { Sulit dalam menulis, tetapi } \\
\text { pandai bercerita }\end{array}$ & 22 dan 31 & 24 \\
\hline & $\begin{array}{l}\text { Biasanya pembicara yang } \\
\text { fasih }\end{array}$ & 35 dan 40 & 38 \\
\hline & $\begin{array}{l}\text { Lebih mudah meningat apa yang } \\
\text { didengar daripada dilihat }\end{array}$ & 27 dan 28 & 41 \\
\hline & $\begin{array}{l}\text { Suka berbicaradan menjelaskan } \\
\text { sesuatu panjang lebar serta } \\
\text { melakukan diskusi }\end{array}$ & 37 dan 39 & 42 \\
\hline \multirow[t]{7}{*}{ 3. Kinestetik } & $\begin{array}{l}\text { Berbicara pelan dan } \\
\text { lambat }\end{array}$ & 43 dan 47 & 50 \\
\hline & $\begin{array}{l}\text { Menyentuh orang agar } \\
\text { mendapat perhatian }\end{array}$ & 48 dan 54 & 45 \\
\hline & $\begin{array}{l}\text { Selalu berorientasi pada fisik } \\
\text { dan banyak gerak }\end{array}$ & 49 dan 61 & 46 \\
\hline & Lebih memanipulasi dan praktik & 44 dan 52 & 53 \\
\hline & $\begin{array}{l}\text { Menggunakan jari sebagai } \\
\text { petunjuk saat membaca }\end{array}$ & 55 dan 56 & 63 \\
\hline & Tidak dapat duduk diam & 51 dan 62 & 59 \\
\hline & $\begin{array}{l}\text { Sulit mengingat lokasi/ tempat, } \\
\text { kecuali jika mereka pernah } \\
\text { berada di tempat itu }\end{array}$ & 58 dan 60 & 57 \\
\hline
\end{tabular}

\section{HASIL DAN PEMBAHASAN}

Pada dasarnya, seluruh proses pembelajaran bertujuan untuk dapat memberikan tambahan pengetahuan berupa informasi-informasi yang disampaikan oleh Guru kepada seluruh peserta didiknya. Tetapi pada prakteknya, di lapangan masih saja banyak ditemukan adanya kesulitan- 
kesulitan yang dialami oleh siswa ketika menerima dan mengolah informasi yang diberikan.. Kesulitan yang mereka alami bisa dilihat melalui hasil pemecahan permasalahan matematika siswa yang cenderung masih rendah, bahkan Indonesia hanya mampu mencapai peringkat ke-64 dari 72 negara dalam hal kemampuan pemecahan masalah yang telah disebutkan dalam PISA (Programme Internationale for Student Assesment) dan lagi-lagi pendidikan Indonesia hanya mampu menempati posisi ke 57 dari 65 negara secara keseluruhan, seperti yang telah diterbitkan oleh Organisation for Economic Cooperation and Development (OECD) (Wahyudi dan Anugraheni, 2017).

Berdasarkan data angket yang telah diperoleh dari siswa kelas VIIIA dan VIIIB SMP Negeri 1 Arjasa, maka dapat diinformasikan bahwa:

Tabel 2 Hasil Tabulasi Perolehan Data Gaya Belajar Siswa

\begin{tabular}{clccc}
\hline No & Gaya Belajar & Kelas VIIIA & Kelas VIIIB & Total \\
\hline 1 & Visual & 14 & 12 & 26 \\
\hline 2 & Audio & 10 & 8 & 18 \\
\hline 3 & Kinestetik & 0 & 3 & 3 \\
\hline 4 & Visual-Audio & 5 & 4 & 9 \\
\hline 5 & Visual-Kinestetik & 0 & 0 & 0 \\
\hline 6 & Audio-Kinestetik & 0 & 1 & 1 \\
\hline 7 & $\begin{array}{l}\text { Visual-Audio- } \\
\text { Kinestetik }\end{array}$ & 1 & 0 & 1 \\
\hline & $\quad$ Jumlah & 30 & 28 & 58 \\
\hline
\end{tabular}

Dari data pada Tabel 2 terlihat bahwa pada kelas VIII A siswa dengan kecenderungan visual sebanyak 14 orang, audio sebanyak 10 orang, visualaudio sebanyak 5 siswa dan visual-audio-kinestetik sebanyak 1 siswa. Sedangkan untuk kelas VIIIB diperoleh data bahwa siswa dengan kecenderungan visual sebanyak 12 siswa, audio sebanyak 8 siswa, kinestetik sebanyak 3 siswa, visual-audio sebanyak 4 siswa dan audio-kinestetik sebanyak 1 siswa. Data ini menunjukkan bahwa pada kelas VIIIA terdapat 4 macam kombinasi gaya belajar yang berbeda dan 5 macam kombinasi untuk gaya belajar yang berbeda di kelas VIIIB.

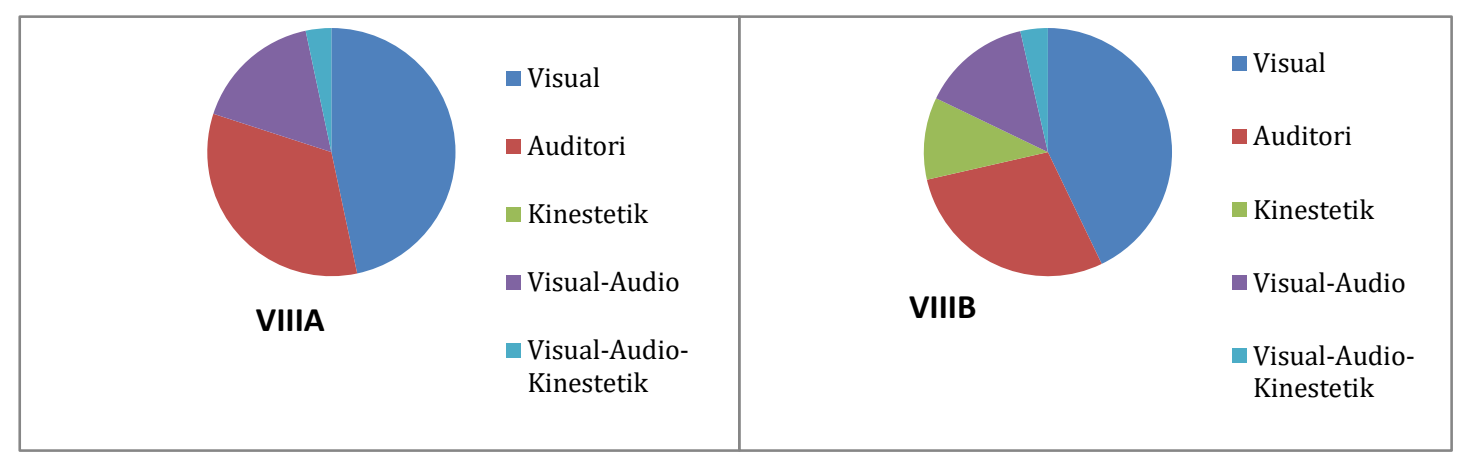

Diagram 1 Perolehan Gaya Belajar Siswa 
Diagram 1 menunjukkan bahwa di kelas VIIIA terdapat 46,67\% siswa visual, 33,33\% siswa audio, 16,67\% siswa visual-audio dan 3, 33\% siswa visual-audio-kinestetik. Untuk kelas VIIIB diperoleh persentase sebanyak 42,86\% siswa visual, 28,57\% siswa audio, 10,71\% siswa kinestetik, 14,29\% siswa visual audio dan 3,57\% siswa audio-kinestetik. Hal ini sesuai dengan penelitian yang telah dilakukan oleh Juliani (2016) yang menyatakan bahwa dalam satu kelas terdapat persentase gaya belajar visual (46\%), auditori (18\%) dan kinestetik (35,33\%). Serta penelitian Maula (2017) yang menyatakan bahwa siswa yang memiliki gaya belajar visual sebanyak 37 siswa $(59,68 \%)$, diikuti gaya belajar auditorial sebanyak 15 siswa $(24,19 \%)$, dan kinestetik sebanyak 10 siswa (16,13\%).

Sebagaimana yang telah dikemukakan Bire, dkk (2014)tentang "gaya belajar visual, kinestetik dan audio memiliki hubungan yang positif dengan prestasi belajar". Koefisien korelasi untuk masing-masing gaya belajar audio, visual, dan kinestetik berturut-turut adalah sebesar 0,080; 0,043; dan 0,079 yang berarti bahwa penggunaan masing-masing gaya belajar visual, gaya belajar auditorial, dan gaya belajar kinestetik semakin ditingkatkan maka akan meningkat pula prestasi belajar yang dimiliki. Sebaliknya, pada kenyataannya di lapangan, peneliti menemukan bahwa 64\% hasil belajar siswa di kelas masuk ke dalam kategori rendah. Ini sangat bertentangan dengan pendapat Bire tersebut.

Hal ini juga dapat disebabkan oleh kecenderungan siswa untuk mempelajari hal yang sangat beragam dan dapat dipengaruhi oleh banyak hal termasuk cara mereka dalam menyerap danmengolah informasi serta perbedaan kebiasaan merepresentasikan dalam kehidupan nyata mereka (biasanya disebut dengan tipe belajar) ataupun adanya pengaruh dari "faktor dari dalam seperti kemauan belajarkecerdasan,motivasi, minat, kondisi psikis,, kondisi fisik, danbakat" dan "faktor luar yang meliputi lingkungan keluarga, lingkungan sekolah, dan lingkungan sosialnya” (Suan, 2013: 27).

Hasil lain yang juga didapatkan adalah bahwa siswa visual lebih cenderung suka mencatat rumus matematika dengan memberikan tanda tertentu seperti garis bawah atau warna lain, menyimpan kembali buku dan alat tulis setelah selesai belajar, dan mereka lebih memahami materi dengan cara membaca. Ini semua menunjukkan ciri-ciri gaya belajar visual yang sesuai dengan pendapat De Poter \& Henacki (1999) yang menyatakan bahwa orang visual lebih mampu memahami dengan membaca dan pendapat Hamzah (2008) yang menyatakan bahwa "Orang visual akan melihat atau membayangkan apa yang sedang dia bicarakan. Selain itu, orang tersebutpeka terhadap warna dancukup paham terhadappadapermasalahan artistic.".

Sedangkan untuk siswa auditorial, subjek yang berada di lapangan menunjukkan bahwa mereka cenderung kesulitan berkonsentrasi dalam 
membaca ketika lingkungan berisik serta lebih senang berdiskusi ataupun bercerita dalam pembelajaran. Hal ini juga mampu mendukung teori tentang ciri-ciri siswa audio yang sesuai dengan pendapat Bobby De Porter dan Mike Hernacki (Depoter,2016) yang menyatakan bahwa "ciri- ciri siswa dengan gaya belajar auditorial adalah (a) sering berbicara kepada diri sendiri saat bekerja, (b) mudah terganggu keributan sekitarnya, (c) senang membaca dengan keras dan mendengarkan, (d) merasa kesulitan untuk menulis, tetapi hebat dalam bercerita."

Siswa dengan gaya belajar kinestetik memiliki kecenderungan belajar antara lain dalam pembelajaran matematika mereka lebih suka jika disuruh untuk berlatih daripada menghafalkan rumus, selalu melakukan gerakangerakan yang tidak mereka sadari ketika mereka memahami sesuatu, mampu mengoperasikan alat tanpa perlu membaca petunjuknya terlebih dahulu dan mereka menggunakan jari-jarinya untuk menunjuk ketika membaca. Aktivitas- aktvitas ini juga sesuai dengan pendapat Bobby De Porter dan Mike Hernacki (Deporter,2000) yang menyatakan bahwa ciri-ciri siswa dengan gaya belajar kinestetik yaitu: "menggunakan jari sebagai petunjuk saat membaca, tidak dapat duduk diam untuk waktu yang lama, kemungkinannya tulisannya jelek, selalu berorientasi pada fisik dan banyak bergerak, ingin melakukan segala sesuatu".

Berdasarkan hasil dan pembahasan yang telah dilakukan, beruntungnya di SMPN 1 Arjasa tersebut telah disediakan fasilitas pendukung pembelajaran yang cukup memadai, seperti perpustakaan, audio system, infocus, laboratorium, lapangan, dan ruangan belajar yang nyaman yang tentunya itu semua dapat membantu siswa mengurangi kesulitan-kesulitan belajarnya yang disebabkan oleh perbedaan gaya belajar mereka.

\section{KESIMPULAN DAN SARAN}

Berdasarkan hasil penelitian serta pembahasan yang telah dilakukan peneliti terhadap data-data yang telah didapatkan, maka diperoleh kesimpulan bahwa secara keseluruhan gaya belajar paling banyak yang dimiliki oleh siswa kelas VIII di SMP Negeri 1 Arjasa adalah gaya belajar visual dengan rincian sebaran persentase gaya belajar sebagai berikut: visual sebanyak 44,83\%, audio sebanyak 31,04\%, kinestetik sebanyak 5,17\%, visualaudio sebanyak 15,52\%, audio-kinestetik sebanyak 1,72\%, dan 1,72\% untuk gaya belajar visual-audio-kinestetik.

Sehingga sesuai dengan hasil penelitian yang didapatkan maka sebaiknya Guru dapat menggunakan berbagai macam metode pembelajaran dengan mengkombinasikan keseluruhan gaya belajar $V A K$, Guru juga sebaiknya memberikan bimbingan dan waktu untuk membantu siswa menemukan gaya/tipe belajar yang sesuai dengan diri mereka, serta siswa 
dapat membentuk kelompok-kelompok kecil untuk belajar hingga mereka mampu mengoptimalkan kemampuan masing-masing untuk membantu temannya yang lain.

\section{DAFTAR PUSTAKA}

Bire, A.L., Geradus, U., \& Bire, Josua. (2014). Pengaruh Gaya Belajar Visual, Auditorial, dan Kinestetik Terhadap Prestasi Belajar Siswa. Jurnal Kependidikan, 4 (2), 168-174.

Depdiknas. (2017). Peraturan Menteri Pendidikan dan Kebudayaan Republik Indonesia No. 17 Tahun 2017 tentang Penerimaan Peserta Didik Baru pada Taman Kanak-Kanak, Sekolah Dasar, Sekolah Menengah Pertama, Sekolah Menengah Atas, Sekolah Menengah Kejuruan, atau Bentuk Lain yang Sederajat. Jakarta: Departemen Pendidikan Nasional.

DePorter, B dan Hernacki, M. (1999). Quantum Learning. Bandung: Kaifa Learning.

DePorter, B dan Hernacki, M. (2016). Quantum Learning Membiasakan Belajar Nyaman dan Menyenangkan. Bandung: Kaifa Learning.

Elliot, A., Henrly, K., Sell, M. \& Maier, M. (2013). Achievement goals, performance contingencies, and performance attainment: An experimental test. Journal of Education Psychology, 97(4), 630-640.

Gunawan, A.W. (2003). Genius Learning Strategy. Jakarta: PT. Gramedia Pustaka Utama.

Hamzah. (2008). Orientasi Baru dalam Psikologi Pembelajaran. Jakarta: PT Bumi Aksara.

Juliani, Ni Wayan., dkk. (2016). Analisis Gaya Belajar Siswa dalam Pembelajaran Bahasa Indonesia pada Siswa Kelas V SD Gugus VI Kecamatan Abang Kabupaten Karangasem Tahun Pelajaran 2015/2016. E-Journal PGSD Universitas Pendidikan Ganesha Jurusan PGSD, 4 (1).

Kemendikbud. (2016). Karakteristik Siswa SMP dan Bilangan Guru Pembelajar, Modul Matematika SMP, Kelompok Kompetensi A. Jakarta: Dirjen Guru dan Tenaga Kependidikan Kemendikbud.

Maula, Faizatin Qisthi. (2017). Gaya Belajar Siswa Kelas VIII SMP Negeri 1 Boja pada Mata Pelajaran IPA Biologi. UNNES: Skripsi tidak dipublikasikan (0nline). https://lib.unnes.ac.id/24658/1/4401412045.pdf.

Miller, Richard C. (1990). Discovering Mathematical Talent. ERIC Digests, ERIC Development Team. 
Rezaeinejad, M., Akbar, A., \& Gowhary, H. (2015). The Study of Learning Styles and Its Relationship with Educational Achievement among Iranian High School Students. GlobELT: An International Conference on Teaching and Learning English as an Additional Language. Antalya-Turkey.

Saputra, Aldino. (2018). Hubungan Antara Gaya Belajar dengan Hasil Belajar Matematika Siswa Kelas IV SD Negeri 1 Way Laga Bandar Lampung. Bandar Lampung. Skripsi tidak dipublikasikan (0nline). http://digilib.unila.ac.id/32160/3/SKRIPSI\%20TANPA\%20BAB\%20P EMBAHASAN.pdf.

Suan, E. B. (2013). Analisis Faktor-Faktor yang mempengaruhi Prestasi Belajar Siswa SMP pada Panti Asuhan di Kota Kupang pada Semester Ganjil Tahun Ajaran 2012/2013. Tesis Program Pascasarjana Udayana.

Sundayana, Rostina. (2016). Kaitan Antara Gaya Belajar, Kemandirian Belajar, dan Kemampuan Pemecahan Masalah Siswa SMP dalam Pelajaran Matematika. Pendidikan Matematika STKIP Garut. (Online). Tersedia: https://media.neliti.com/media/publications/226695-kaitan-antaragaya-belajar-kemandirian-b-3dcfcaeb.pdf (Diakses pada tanggal 05 April 2018).

Syaharuddin. (2016). Deskripsi Kemampuan Pemecahan Masalah Matematika dalam Hubungan dengan Pemahaman Konsep Ditinjau dari Gaya Belajar Siswa Kelas VIII 4 Binamu Kabupaten Jeneponto. Program Pascasarjana Universitas Negeri Makasar.

Wahyudi, dan Anugraheni, I. (2017). Strategi Pemecahan Masalah Matematika. Salatiga: Satya Wacana University Press.

Wahyuni, Yusri. (2017). Identifikasi Gaya Belajar (Visual, Auditorial, Kinestetik) Mahasiswa Pendidikan Matematika Universitas Bung Hatta. Jurnal Penelitian dan Pembelajaran Matematika Universitas Sultan Ageng Tirtayasa, 10 (2), 128-132.

Widiyanti, Teti. (2011). Pengaruh Gaya Belajar Terhadap Kemampuan Pemecahan Masalah Matematika. Fakultas Ilmu Tarbiyah dan Pendidikan Universitas Islam Negeri Syarif Hidayatullah Jakarta. (Online). Tersedia: http://repository.uinjkt.ac.id/dspace/bitstream/123456789/5755/1 LTETI\%20WIDIYANTI-FITK. Diakses pada tanggal 05 April 2018. 